\title{
Writing in and Out of Exile: A Foucauldean Reading of No Friend but the Mountains by Behrouz Boochani
}

\author{
Hanna Merin Varghese
}

\begin{abstract}
Refugee" is a historically constructed term that privileged concerns that are substantially ideological and political rather than economic and ecological. But one cannot neglect the fact that environmental and economic concerns cannot be set apart from the political and hence rises the necessity to create a new inclusive category of "essential needs" to consider their intrinsic interconnectivity as its one of the apriorism. Refugee literature essentially addresses not only the displacement but the gaps that are found in the sociological approach to "statelessness" and migration. On the other hand, literature stands for individual expressions and experience. Literature in the context of statelessness not only signifies the notion of being a "refugee" but being an " asylum, seeker" as well. No Friend but the Mountains by Behrouz Boochani is such an autobigraphcial novel written in the backdrop of his experience as an asylum seeker and consequent incarceration in the Australian detention regime. The Australian detention centre is built and worked in such a way that it satisfies the idea of the panopticon. The Kyriarchal system works in the prison even in a way that affects the psyche of the imprisoned individuals and thus these stateless asylum seekers undergo extreme existential dilemmas and commit severe crimes, turning against one another and sometimes even suicides. On the basis of the experiences of Boochani, the carceral system of Australian detention centre is expounded here through a Foucaludean idea of punishment, Bentham's notion of the panopticon as well Fiorenza's idea of kyriarchy where all of them are essentially different shades and shapes of exerting power.
\end{abstract}

Keywords: Detention, Discipline, Existence, Foucault, Incarceration, Kyriarchy, Prison, Punishment, and Refugee.

\section{INTRODUCTION}

This paper titled "Writing in and out of Exile: A Foucauldian Reading of No Friend but the Mountains by Behrouz Boochani” examines the dynamics of power in both refugee determination and detention systems. It challenges both the views that determination systems of a majority of nations encompass rational decision-making processes and the critical view that sees determination procedures as an instrument of the state. It argues that using a Foucauldian analysis of power, one is better placed to understand how refugee systems work and to understand the implications for

Manuscript received on June 20, 2021.

Revised Manuscript received on July 16, 2021.

Manuscript published on July 30, 2021.

* Correspondence Author

Hanna Merin Varghese*, English Literature, Baeslius College, Kottayam (Kerala), India.

(C) The Authors. Published by Blue Eyes Intelligence Engineering and Sciences Publication (BEIESP). This is an open access article under the CC BY-NC-ND license (http://creativecommons.org/licenses/by-nc-nd/4.0/) different actors in these systems. The central argument of the paper is explicated using the Foucauldian idea of 'Prison and punishment' explained in his Discipline and Punish in which he used three different but interrelated factors to explain punishment which includes; "power", "knowledge" and "the body".

A stateless person is someone who does not possess citizenship of any country where citizenship is the legal bond between a government and an individual and allows for certain social, economic, and political and other rights of the individual, as well as the responsibilities of both government and citizen. A person can become stateless due to a variety of reasons that may be sovereign, legal, technical or administrative decisions or oversights (IJR centre). The Universal Declaration of Human Rights emphasises that "Everyone has the right to a nationality." But often this right to have a nationality is denied and thus an individual becomes forced to flee his or her own country.

When people flee their own country and seek sanctuary in another country, they apply for asylum (the right to be recognized as a refugee and to receive legal protection and material assistance). The asylum seeker must be able to demonstrate that his or her fear of persecution in his or her home country is well-founded. But in reality, most asylum seekers are never recognized as refugees and they are driven into incarceration or detention centres that hold beautiful pet names that essentially hide their real intentions. It happens mainly because of that country's xenophobic tendencies, border-industrial complexes etc. No Friend but the Mountains is a work written by such an imprisoned asylum seeker named Behrouz Boochani about the devilish cruelties and existential dilemma that he has been suffering inside the detention centre.

This prison narrative that reflects a Kafkaesque fate of refugees uses many distinctive narrative techniques common in the traditional and contemporary storytelling practices of Iranic people. It can also be read as a mixture of Kurdish folklore, Persian literature, local histories and natural symbols, rituals and ceremonies. Omid Tofighian says that the work is a decolonial text, and fuses literature with political commentary and language from different discourses. He interprets the genre as 'horrific surrealism'. It has connections with horror realism and culturally or ethnically situated forms of surrealism. The descriptive prose sometimes intermingles with bits of poetry reflects the emotional reactions to the factual statements.

Published By:

Blue Eyes Intelligence Engineering

\& Sciences Publication

(C) Copyright: All rights reserved. 
Boochani's style exhibits features of naturalism in ways that manifest in the works of Sherzad Hassan.

His use of dreams and visions can be attributed to the influence of poet Sherko Bekas for his sense of surrealism and introspection, his work can be compared with the poetry of Dalwar Qaradaghi. Through his technique of naming, he has brought a new abstract entity into existence, a scholarly term for a being that representing the multi-structure nature of border - industrial complex of Australia - a being that orchestrates the systematic torture inflicted in the Manus Prison - The Kyriarchal System.

Omid Tofighian, in The translator's Tale of the work, states about the purpose or aim of this work as: "This book Functions to manoeuvre readers to resist the colonial mindset that's driving Australia's detention regime and to inspire self -reflection, deep investigation, and direct action...The Shared philosophical project is open-ended - it is an open call to action."

\section{DISCIPLINE AND PUNISH: A FOUCAULDIAN VIEW OF PRISON}

The French philosopher and postmodernist, Paul Michel Foucault has been hugely influential in shaping the understandings of power, drawing from the analysis of those who use power as an instrument of coercion, and from the prudent structures in which those actors operate, toward the idea that 'power is everywhere' embodied in discourse, knowledge, and regimes of truth. For Foucault power operates on quite a different level from other theories.

Foucault has had influence not only in philosophy but also in a large range of humanistic and social scientific disciplines. Discipline and Punish: The Birth of the Prison (1975) by Foucault, analyses the penal system and a genealogical study of the development of the modern way of imprisoning criminals rather than physically torturing and sentencing them to death. He emphasizes the fact how these "reforms" became a vehicle for more effective control: "to punish better but less' and thus he argues that prison became the principal form of punishment not just because of the humanitarian concerns of reformists. He examines the penal system and explains its gradual transition/progress from execution to incarceration and total control over the prisoners. Foucault explains how total controls over the prisoners and the strict discipline in the prisons have conditioned the substitution of physical chastisement with psychological torture.

According to Foucault, punishment is to be understood as a "political tactic" situated within the general field of power relations. Foucault has set out three interrelated concepts that he used to examine the fundamentals of any structure of domination, and they can be used in order to study the "punishment". They are, "power," "knowledge," and "the body". The ultimate material that is shaped and seized by all penal, political, cultural, and economic institutions is nothing but the human "body". All the systems of domination depend on the subjugation of these bodies, as what they require is an obedient, disciplined body, which is useful to them to a greater or lesser degree where some institutions master the body from outside (using physical force) while other institutions by internalizing or producing an individual who does what is needed as a habitual thing without external force.

Despite being titled The Birth of the Prison, it is an exploration of how domination is achieved and individuals are socially constructed in terms of power in the modern world. He observes the transition in punishment or penal styles as a qualitative shift rather than as a decrease in intensity of the punishment. Only the target of the punishment is shifted, where the measures now aim at the "soul" of the offender rather than just to punish the body. "This means that the 'pain' at the heart of punishment is not the actual sensation of pain, but the idea of pain, displeasure, inconvenience - the 'pain' of the idea of the pain" (Foucault 94).

According to Foucault, this change in punishment has affected the judgments and justice in a way that it shifted its focus to questions of character, individual history, and environment and the effect is that this system is not so much corrective. Thus for Foucault, there is a "micro-physics of power" where power comes into contact with the bodies of subjects at an operative point and it has its bodily materiality and effects. He focuses on abstract power structures, institutions and strategies rather than the concrete power politics and the people involved in it.

The third concept is that of "knowledge", knowledge of the target, on which their strategies and techniques depend etc. In the words of David Garland:

The successful control of an object - whether it is an object in nature or a human object - requires a degree of understanding of its forces, its reactions, its strength and weaknesses, and its possibilities. Conversely, the more it is known, the more controllable it becomes. (Garland. 853)

For Foucault, discipline "is an art of the human body" (Foucault.137) and also he states that it is a "political anatomy of detail" (139). It is operating on a smaller scale of control, focusing on the individual movements and gestures rather than paying attention to the whole body. Examples for this can be drawn from classrooms, army, hospitals, workshops etc.

The natural recalcitrance of individual or disobedience to the institutions are dealt with a method what Foucault calls" normalization", which is essentially corrective rather than punitive in nature. In other words, it is a method of conformity rather than expiation and retribution. This system also includes "examination" or a "surveillance" which allows a closer observation, differentiation, assessment of standards and identification of a failure in conformity. For Foucault, the very act of this observation and examination within itself is a form of exercising power and control over the individuals within their "gaze".

In discipline, it's the themes that need to be seen. Their visibility assures the hold of the power that is exercised over them. It is the very fact of being constantly seen, of having the ability always to be seen, that maintains the disciplined individual in his subjection. (187)

Jeremy Bentham's "panopticon" is another idea that epitomises this power principle. It is an architectural form designed to render individuals constantly under surveillance, subject, and knowledge of authorities. 
Here, the physical repression is replaced by a "refined", "gentler", and more effective structure of domination, which does not depend on the strength of those who occupy the power positions. Not many prisons were built on Bentham's model, the surveillance cameras have done the duty effectively and have made itself a panopticon and this had been great for capitalism (Pratt. 374).

How is that the power to be strengthened in such that, faraway from impeding progress, faraway from weighing upon it with its rules and regulations, it actually facilitates such progress? What intensification of power is going to be able at an equivalent time to be a multiplicator of production? How will power, by increasing its forces, be ready to increase those of society rather than confiscating them or impeding them? The panopticon's solution to this problem is that the productive increase of power can be assured only if, on the other hand. It is often exercised continuously within the very foundations of society, within the subtlest possible way, and if, on the opposite hand it functions outside these sudden, violent, discontinuous forms that are bound up with the exercise of sovereignty. (Foucault. 208)

For Foucault, the prison is a mirror to society. It is not a marginal building on the edge of a town but is closely integrated into it. The mechanisms of discipline and the strategies of power and knowledge operated are the same both for the citizens and for the criminals. Therefore Foucault argues that the prison is often considered as a "carceral network" that spread throughout the society, which is infiltrating also as penetrating everywhere.

\section{MANUS ISLAND: A FOUCAULDEAN CONCEPTION OF DISCIPLINARY POWER}

Is the Foucauldian conception of disciplinary power still at work in contemporary sorts of imprisonment? Manus Prison depicted in Behrouz Boochani's autobiographical account of exile called No Friend but the Mountains is an answer to the very question.

No Friend but the Mountains: Writing from Manus Prison by Behrouz Boochani represents a fusion of political commentary, poetry, journalistic accounts and philosophical reflections with Kurdish folklore, Iranian myths, and epics. He has written the work from the standpoint of an indigenous Kurdish writer, but a stateless refugee, by experimenting with different genres and thus creating a different framework to explain the offshore detention system as a carceral system and his enigmatic experiences in exile. The narratives that he creates, works as a philosophical as well as a political critique and expose the Manus Island Regional Offshore Processing Centre as a modern manifestation of systematic torture.

The established genres have limitations to articulate the psychological and physical tortures that the refugees in exile have gone through and thus Boochani has produced another prison narrative depicting a surreal form of horror. Boochani finds the existing theories insufficient to explain the refugee problems and the tortures in the detention centre in Manus and thus he has formulated a special theory by himself that is known as "Manus Prison Theory" and its major concern is:

How the institution of Manus Prison, with its multipronged practices as part of a wider border-industrial complex, was organized to stifle the pursuits for truth and understanding. In other words, Manus Prison as an ideology hinders or eliminates opportunities to 'know'; to know in nuanced and multidimensional ways both about the violent atrocities about the unique lived experiences of the prisoners. (Boochani)

His theory can be understood better by reading it from a Foucauldian point of view. The main elements of disciplinary power as Foucault frames in his Discipline and Punish: the omnipresent surveillance, categorization, classification, the time -table, and non-idleness, aim at reshaping the subjectivity of the delinquent. Foucault claims that: the prison would become "a machine for altering the mind." Scholars like David Garland and Karl Von Schriltz argue that such a mechanism does not exist but in contrast to their disagreement one could observe this mechanism which alters the mind in Boochani's work; The Regional Offshore Processing Centre at Manus Island. His conception of an administrative machine is for altering minds and shaping subjectivity to create a specific sense of Self and Other. Boochani throughout his work emphasizes the psychological change that he and his fellow refugees have undergone for six years of confinement (but in a different way). He, in his conversation with the translator, says that:

The refugees held in Manus Prison has modified their perception and understanding of life, transformed their interpretation of existence, matured their notion of freedom.

They have changed so much - they have transfigured into different beings... this has occurred for everyone. The process has been unsettling and vexed, and some have become cynical and pessimistic of the world and life. But in any case, all of them are unique in their special way; they have become distinctly creative humans, they have unprecedented creative capacities, and in my view, this is incredible, it is phenomenal to witness. (Boochani)

The book begins with the perilous journey that he and his fellow refugees had, to their dream Island, to Australia. In the first four chapters, he describes his eventful journey, and there one could notice that he names them hiding the identity of his fellow travellers. He names them with mythical characters and names from Kurdish folk tradition like Golshifteh and Mani. But after he enters the Manus prison, he names and identifies his fellow prisoners with their physical attributes and behaviours like Maysam the Whore and The Gentle Giant. This shift in the simplest thing tells everything about Foucault's 'alteration of minds'. Foucault argues that the new penal system which gives lesser importance to the body has a special concern with the "soul" of the offender. This new penal system attacks the psyche. The detention system of Manus has effectively made the "uncharged" prisoners feel like "four hundred lost souls in a tightly confined space" (Boochani). They call themselves "animals" in a zoo rather than human beings. The disciplinary power that works in the Manus has trained them to observe themselves as culprits though they came there seeking asylum. Thus, Boochani adds that the psyche of prisoners has become a "brew of images", who are captive of their past which on the other side destroy their existing sense of self (Boochani).

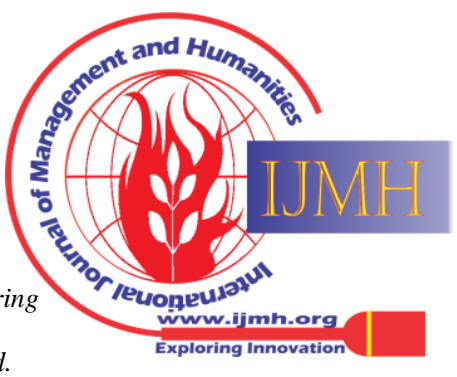


For him, discipline is not a part of any institution. It is a "style of power", which comprise a whole set of instruments, techniques, levels of applications, targets, and procedures.

Categorisation and classification are the major elements in the conception of disciplinary power and the Australian authorities have successfully done that in Manus Prison. Classifying and categorising can be observed in the Kyriarchal system that is working in the prison. The IHMS system in the camp which is meant for the sick prisoners has developed a categorisation within the schedule of consultation as, schedule A that is meant for the prisoners in "extremely terrible state", schedule B for prisoners in "terrible state" and in the end, schedule C. Yet the prisoners are fooled, they compete until they push each other aside, out of the way, so that they can reach the Schedule A. But the Schedule $\mathrm{A}$ is an unattainable dream where in fact, there is no schedule A. This categorisation is a "respectful" psychological game of kyriarchy. Boochani calls it respectful because the system through this virtual categorisation allows no one no longer to act violently, a strategic categorisation to make the authorities safe. Categorisation of three prisons such as Fox prison Delta prison and Mike prison is another strategy employed in Manus which functioned to create animosity and hostility among the prisoners. They aim at breeding hatred among the prisoners which will eventually make them return to their homeland though the land they left offers no solace.

"In the prison, hatred makes prisoners more insular. The weight of the hatred is so tense that the prisoners will suddenly collapse on a night and give up resisting... surrender to a system that induces and amplify hatred... and accept refoulement"( Boochani).

The categorisation and classification in Manus prison was a part of the forced surrender of prisoners to the authorities without any further resistance.

The fundamental concepts with which discipline and punishment can be studied are "power", "knowledge", and "the body". Beginning with "the body", Nietzsche, Deleuze and Guattari say that, the human body is the ultimate material that can be seized and shaped by all possible institutions. This is done in two ways first, by external mastery and second, through the process of internalization, where Foucault favours the latter most (Harcourt. 29- 51). Both of these can be observed in Boochani's work. The location and the architecture of the prison itself can be observed as part of a strategic plan to torture the body without direct interference. He describes the location as "the tropical location of Manus has the most ruthless sun and the entire world/ as soon as it gets the chance, it cremates everything". These asylum seekers who haven't done anything wrong are taken to this land to suffer physically for which Boochani identifies strong political reasons behind it which include Australia's border-industrial complex, extreme xenophobia, and coloniality. He describes the prison as a "confrontation of 'bodies', -a confrontation of human flesh." It looks like a cage or more like a beehive with countless bees, which suffocates the inmates with the friction of human smell and breath. They all stink like a "fast rotting corpse". The architect of the building certainly did not create it for the humans to occupy. It looks like "a battlefield". The 'Oldman Generator" which is purposefully switched of at the midnight during the hours of sleep within the extreme tropic climate is another example of torture without the direct contact of power holders. control the body. He writes; 'the spectacle of the prison queue may be a raw and palpable reinforcement of torture.' He finds a disciplinary power relation even behind the starvation. According to Boochani, starvation can be understood with two objectives, the first, for implementing a handful of controlling mechanisms on the prisoner's minds and second, for making them complicit and enmeshed in this system.

Direct physical torture has also its examples in Manus Prison. Chapter ten named Chanting of Crickets, Ceremonies of Cruelty / A Mythic Topography of Manus Prison well explains it. Boochani witnesses the torture that is done to the man he calls "The Prophet" who is put in solitary confinement (Green Zone) within the Manus Prison: 'the prophet is a piece of meat crushed beneath the weight of arms and legs.'

Another method by which the body is tortured is by normalization or habitually doing something without the force or demand of the authorities. Plenty of examples can be cited from the Manus for this process of normalization. The meal queues' tactical torture has become normalized for the prisoners and thus every day with a uniformity, everybody forms a queue which can be called a domesticating process and Boochani says that every mind has caught up in a process, a process that became normalized and thus he infers that these meal queues have agency, and it tries to establish the notion that the individual who behaves most brutish and despicable way can feature the most easier lifestyle and it becomes the justice as well as it becomes a principle where more inmates try to acculture it.

For the prisoners of Manus, suffering has become normalized and he observes that people experience a particular joy. A twisted satisfaction in chaos and destruction. Everything is mechanical and micromanaged. For the prisoners, it is a twisted system that governs the prison, a system that leaves the prisoner simply trying to cope. An extremely oppressive form of governance that the prisoner internalizes! A system leaves the prisoner simply trying to cope.

The second fundamental concept is "power". For Foucault it cannot be thought of as a property of particular classes or of individuals who have it, rather it is an instrument that they use at will. It refers to the various forms of domination and subordination that works "wherever and whenever social relations exist". It does not display a singular pattern as life takes place in a multiplicity of fields of power. Foucault focuses primarily on the way the power is implemented and these power relations are organized rather than the individuals who exert the power and who are subjected to the force. Boochani identifies the worst implementation of power in food supplies. It has no logic. The only logic with which it operates is nothing but domination. The prison regulates the quantities of things and limits the time. It means that the one who needs food has to suffer. The system of the prison sometimes withholds supplies; which is a clear strategy for conditioning prisoners, forcing them to behave badly. Eating is a necessity and the worst domination is over it.

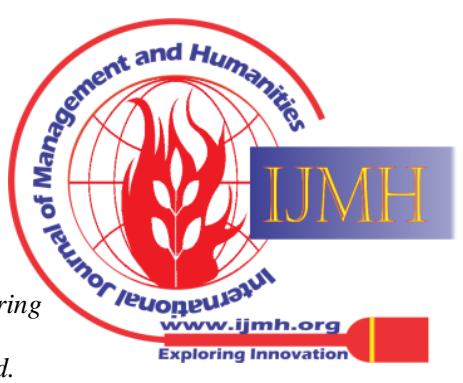


Boochani sums up the power domination over eating as:

The system can be summed up in one way: first, a condition of dependency is established, then that dependency is framed in the context of micro-level and macro-level governmentality - even though the interconnections vary.

Eating is a necessity and prisoners have no choice but to hustle to meet this basic need and this is the tactic used to keep them in captivity. Like being caught in a spider's web, the harder you struggle, the more entangled you become. (Boochani)

The bureaucratic ranks are determined within the prison by relationships of power. Every officer or guard obeys the orders of their "boss". Whenever they are questioned by the prisoners in extreme circumstances like what happened to "The Father Of The Months - Old Child", they answer that they have to ask their "boss" or their "boss" ordered it. It means that every "boss" is subordinate to another "boss", and the superior boss is subordinate to another "boss". If one were investigating this chain, it would lead to thousands of other "bosses".

The relationship between the forms of power and the bodies on which the power is implemented, involves the third fundamental concept, that is, "knowledge". For Foucault, it is to "know-how". To know the target of power and on what and how its techniques depend. The internal relationship between power and knowledge is so intimate that both depend on each other. Boochani is well aware of the target of the power that is operated over the prisoners. That is why he states that the prison dictates and the prisoners accept that they are wretched and contemptible, - and this system of confinement is absolutely built for them. A system engulfs one's consciousness from deep inside it. It fragments and disorients the prisoner to such an extent that he is alienated from his sense of self. Here Boochani claims that the disciplinary power in the Manus Prison is based upon violence. It has an "appetite for spawning violence". Those imprisoned in the Manus Prison are themselves sacrificial subjects of violence. Violence is the technique on which the disciplinary power in the prison depends to achieve its goals. The system, incites the prisoner to employ violence. This knowledge makes him write as:

Witnessing scenes of blood is a catharsis that purifies the emotions and psyche. The scene is a mirror that reflects the prisoners, and they gaze into it. ... self - harm has become established for some in the prison as a kind of cultural practice. When someone cut themselves, it elicits a form of respect among the prisoners. (Boochani)

It is this knowledge that made him refer to himself as commodities worth barely anything. In addition, it is this same knowledge that made the prisoners rise in protest at the end of the book. The knowledge for Foucault is the knowledge of successful control of an object - requires a degree of understanding of its forces, its reactions, and its strength. Boochani expresses this knowledge with a single term that is "Kyriarchal system" with which the whole administration of Manus Prison is explained. Though the term was coined by the radical feminist Elizabeth Schussler to replace the idea of patriarchy, Boochani has wisely used this term to represent all the established methods and systems in the prison, whose sole aim and objective is to suppress the unprivileged group with the multiple intersecting structures. Foucault has used an entire chapter to explain his idea of "Panopticism" in his work Discipline and Punish. It refers to the constant visibility of the prisoners, which induces self-control on the part of the inmates. According to David Garland:

Power no longer needs to unleash its sanctions, and instead, its objects take it upon themselves to behave in the desired manner. Any remnant of physical repression is thus gradually replaced by a gentle but effective structure of domination...it does not depend on the strength or intentions of those who occupy these positions. (Garland 860)

The examination is the central method of control in the prison. Instead of external actions, the gaze of the watcher is internalized to such an extent that each prisoner becomes his / her guard. Bentham with his panopticon laid down the principle that "power should be visible as well as unverifiable". This operation of the system disindividualises and automates the power. Manus prison is not very different in applying Foucault's Panopticism in the prison. Where ever the prisoner goes, he is surrounded by gazes. Boochani describes the situation that made the most respected inmate of the prison, The Prime Minister to defecate in front of others. This situation makes it clear how the prisoners in Manus were haunted by the gazes.

The queue for the meals is also supervised by the G4S guards. They do nothing, but the prisoners are under their gaze even while eating. The food is supplied under their supervision that they make sure that nobody receives in excess. All the corridors are always under the supervision of these guards though neither they interfere nor they talk to the prisoners. It is in this situation that Boochani talks about his own condition under this surveillance. He prefers solitude and silence, which is seldom found in the prison. During these six years of confinement, he confesses that "a moment of silence, solitude and to feel as though one were standing stripped naked" is his greatest dream. He refers to the G4S guards as watchdogs or attack dogs. Every now and then, these officers write things in their notebooks, which they always carry in their pockets. They note things about "everything and everyone", and they do nothing but sit on their chairs and make sure that their presence is felt. "All the pocket and corners in far-off sections of the prison are dominated by their gaze - eyes tracking us down and committed to pursuit. He describes their gaze like that of hostile animals and he says that it feels worse and captive at night. It seems as though there are no chances of avoiding its pervasive scope. When they were at the Christmas Island prison, the thing was not quite different. They were watched by surveillance cameras.

They allow us to go to the toilets. The toilets also have CCTV cameras. It is really hard to relieve yourself when there is a camera staring down at an indivudal.

Especially if consider that right now there are a few sets of eyes belonging to unfamiliar people monitoring you, watching you on the screen connected to that camera. (Boochani)

In Manus Prison, the omnipresence is not only of the prison guards but also of the fellow inmates, which made it even difficult to breathe.

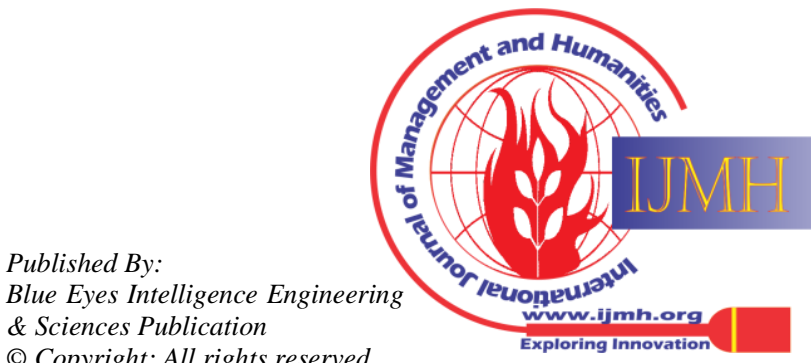


It made the prisoners even more suffocating. An escape from this seldom possible even for a moment without sensing another person's presence. Boochani says that in the midst of it the prisoners learn how to stand in seclusion, even in the midst of a mob, like coconut trees.

He says that there is only one place where he could be alone and it is in toilets. But even there one could not stay peacefully as others will be waiting outside with exploding guts. Speaking about the toilets, one cannot enter the toilets without sensing the looming presence of the officers. Their overbearing presence makes sitting inside the toilets an anxious moment. It is as if their gazes may penetrate the door and pollute the place, disrupting the only freedom that is experienced within the prison. Cubicles are the places where a prisoner burst outs his emotions, being himself where he finds solace for his existential dilemmas.

The cubicles are places for screaming out or they are marked as chambers of devastation, the devastation of youth who have lost their innocence, devastation constituted by absolute hopelessness. A location of the clash between terror, hopelessness, and outbursts of deep anguish. For this reason, the location embodies an uncanny sense of awe, an eerie spirit. (Boochani)

Boochani thus concludes that the government knows exactly what they are capable of - that is why the government have suppressed them.

\section{CONCLUSION}

Richard Flanagan in his foreword to the book No Friend but the Mountains: Writing from Manus Prison writes, "is a book that can rightly take its place on the shelf of world prison literature" (Boochani). Originally written in Farsi by young Kurdish poet, journalist and film producer, Behrouz Boochani, is translated by Omid Tofighian, professor at the University of Sidney, Australia.

All the prisoners in the Manus detention centre have been imprisoned without any charge, conviction, and sentence. They were having a Kafkaesque fate. The Australian government has closed this immigration detention centre on 31 October 2017 with the publishing of the book by Behrouz Boochani.

What has happened on Manus Island is part of Australia's legacy of colonial violence. Throughout the whole years of imprisonment what the system tried to do is to destroy the hope of the prisoners. In "The Translator's Tale", Omid Tofighian observes this work as a text that can be read and understood in multidimensional ways. It is the struggles, which lasted for six years that made Boochani write such a book, which consists of multiple genres, myths, Kurdish folklore, and deeply philosophical insights. And thus the work can be understood in a Foucauldian framework, in terms of his concept of panopticism, discipline, punishment and governmentality.

Foucault has an affinity with rupture or the breaks and he refuses to grant a privileged space of "creator" of the history to the subject, and thus he posits that the subject is "created" by the power - knowledge. What Boochani has done through his work is the same, which he has tried to "know" and thus better-managed things. He summed up the facts that he "knew" as the Kyriarchal system. This Knowledge of the system and its working is explained by him through his autobiographical account of his six years of struggle in the Manus Prison. Tofighian has also documented the story behind the translation functions as a framing narrative for the text itself. The conversation that they had via WhatsApp that are documented and the supplementary essay by the translator gives an insight into the philosophical ideas that are expressed in the text. With the six years of confinement, Boochani has revised the concept of "border" and one could observe a dilemma regarding border in Boochani, same as that of Meena Alexander, expressed through her Fault Lines. He also has tried to invoke the concept of coloniality and thus the relationship between coloniality and forced migration. According to Tofighian, "Behrouz's book is a decolonial text, representing a decolonial way of thinking and doing".

The way that Boochani names his fellow prisoners is notable. As he cannot reveal their real names he has given new names to them and has created characters by mixing and interchanging different attributes of different prisoners. About the naming, Moones explains:

Naming has special aesthetic, interpretative and political functions $\mathrm{n}$ the book. For Behrouz, renaming things is a way to affirm his personhood and establish a sense of authority; naming is a way of reclaiming authority from the prison, disempowering the system, and redirecting sovereignty back to the land. Naming is also part of the creative endeavour, and it works as an analytical tool for examination of the political and material circumstances. (Boochani)

Boochani uses mythical and epic visual imagery, dream visions and a mix of fantasy and reality as a form of magical realism. His literary techniques and forms of expression have connections with horrific surrealism.

Generally, many tropes are used to represent refugee identities, which often diminish their reality and experiences. It is rooted in the dichotomy that the refugees are contrasted with citizens. These tropes include the notions such as refugees as caged persons who escape to the west, desperate supplicant, struggling overcomer who is a battler, broken human being, and a mystic sage etc. "Each of these has the capacity to reduce the refugees to an essentialist, voyeuristic, patronizing and disempowering narratives". Boochani, through his work, has tried to expose reality and break the existing dichotomy.

\section{REFERENCES}

1. "Asylum \& The Rights of Refugees."IJR Centre. 06. June.2021, https://ijrcenter.org/refugee-law/

2. "Foucault / Panopticism: Discipline - Summary." Foucault / Panopticism: Discipline - $\quad$ Summary, culturalstudiesnow.blogspot.com/2017/11/foucault-panopticism-disci pline-summary.html.

3. Betts, Alexander, and Gil Loeschir. Refugees in International Relations. Oxford University Press, 2011.

4. Boochani, Behrouz. No Friend but the Mountains: Writing from Manus Prison. Translated byTofighian, Omid, Picador, 2018.

5. Crenshaw, Kimberle. On Intersectionality: The Essential Writings. The New Press, 2019.

6. Fiorenza, Schussler, Elizabeth. But She Said: Feminist Practices of Biblical Interpretation. Beacon Press, 1992.

7. Foucault, Michel. Discipline and Punish: The Birth of the Prison. Translated by Sheridan,

Alan, Penguin Books, 1991.

8. Garland, David. Foucault's 'discipline and Punish' - An Exposition Critque. American Bar Foundation Research Journal, vol. 11, no.4, 1986, pp.847 - 880. JSTOR, www.jstor.org/stable/828299.

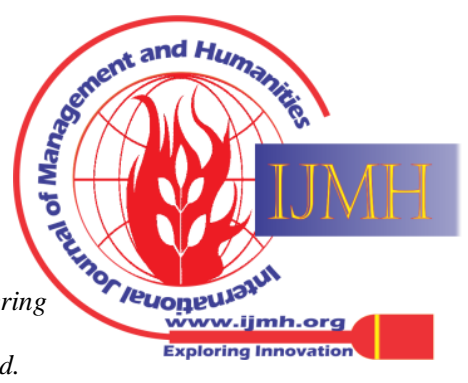


9. Kendall, Gavin, and Gary Wickham. Using Foucault's Metods. Sage Publication,1999.

10. Loughnan, Claire. State Crime Journal, vol. 8, no. 1, 2019, pp. 126-130. JSTOR www.jstor.org/stable/10.13169/statecrime.8.1.0126 . Accessed 18 May 2020.

11. Nguyen, Thanh, Viet. The Displaced: Refugee Writers on Refugee Lives. Abrams Press, 2018.

12. Pratt, John. 'This Is Not a Prison': Foucault, the Panopticon and Pentonville." Social \&amp; Legal

Studies, vol. 2, no. 4, 1993, pp. 373-395. doi:10.1177/096466399300200402.

\section{AUTHORS PROFILE}

Hanna Merin Varghese, Pre- doctoral scholar who has completed postgraduation in English Literature from Baselius College Kottayam, and graduation in English Literature from Devamatha College Kuravilangad, Mahatma Gandhi University and qualified NET in 2019.

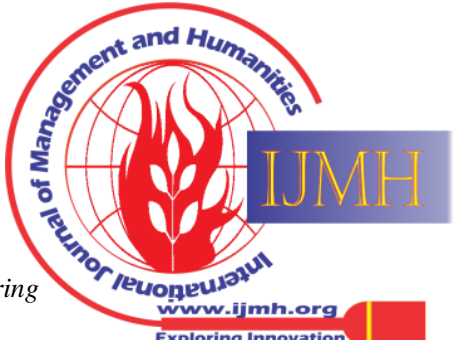

